\title{
Detection of algD, oprL and exoA Genes by New Specific Primers as an Efficient, Rapid and Accurate Procedure for Direct Diagnosis of Pseudomonas aeruginosa Strains in Clinical Samples
}

\author{
Sedighe Rashno Taee ${ }^{1}$; Behzad Khansarinejad ${ }^{1}$; Hamid Abtahi ${ }^{1}$; Mohammad Najafimosleh ${ }^{2}$; \\ Ehsanollah Ghaznavi-Rad ${ }^{1,3}$ \\ ${ }_{2}^{1}$ Department of Medical Microbiology and Immunology, Faculty of Medicine, Arak University of Medical Sciences, Arak, IR Iran \\ ${ }^{2}$ Department of Microbiology, Faculty of Medicine, Hamadan University of Medical Sciences, Hamadan, IR Iran \\ ${ }^{3}$ Molecular Research Center, Faculty of Medicine, Arak University of Medical Sciences, Arak, IR Iran \\ ${ }^{*}$ Corresponding author: Ehsanollah Ghaznavi-Rad, Department of Medical Microbiology, Faculty of Medicine, Arak University of Medical Sciences, Arak, IR Iran. Tel: +98-8634173526, \\ Fax:+98-8634173526, E-mail: e.ghaznavirad@arakmu.ac.ir, ghaznaviehs@yahoo.com
}

Received: July 14, 2013; Revised: September 22, 2013; Accepted: January 22, 2014

\begin{abstract}
Background:Pseudomonas aeruginosa is an opportunistic pathogen that infects patients with cystic fibrosis, burning wounds, ophthalmic traumas and immunodeficiency.

Objectives: The aim of the present study was to compare the efficiency of newly designed primer sets with some previously published primers for PCR detection of exoA, oprL and $\operatorname{algD}$ genes from P. aeruginosa.

Materials and Methods: A total of 150 clinical specimens were inoculated into the routine and selective culture media for P. aeruginosa isolation. Specific primers were designed by bioinformatics analysis for detection of the virulence genes determinants, exoA, oprL and $\operatorname{alg} D$. The sequences of these three genes were obtained from NCBI and multiple alignments were performed to find the conserved sequences of each gene to design the primers. Multiple alignment and primer design steps were carried out by the AlleleID software, version 7.0. Results: Microbiological culture methods resulted 70 P. aeruginosa strains isolated from 70 of the 150 clinical specimens. The results of the PCR assay using the newly designed exoA, oprL and $\operatorname{algD}$ primer sets were positive in 68,70 and 69 clinical samples which represent $97.2 \%$, $100 \%$ and $98 \%$ sensitivity for each primer set, respectively. The PCR results using previously published exoA, oprL and $\operatorname{alg} D$ primer sets were positive only in 57,49 and 28 specimens that correspond to $81.5 \%, 70 \%$ and $40 \%$ sensitivity, respectively.

Conclusions: The results of the present study showed that in comparison with previously published primer sets, P. aeruginosa infection can be diagnosed with higher sensitivity and specificity by the conventional PCR assay using the newly designed primers. It was also shown that the results of the PCR assay on clinical samples of severe infections became positive much earlier than the results of conventional culture method.
\end{abstract}

Keywords:Pseudomonas aeruginosa; Clinical Samples, Detection, PCR

\section{Background}

Pseudomonas aeruginosa is an opportunistic pathogen, which infects patients with cystic fibrosis (1), burning wounds (2), ophthalmic traumas and immunodeficiency. This organism also infects transplant recipients (3). P. aeruginosa is widely distributed, mostly in the hospital field and is one of the most important agents of hospital-acquired infections among Gram-negative bacilli (4). Apart from the inherent drug resistance present in this organism, the acquired simultaneous resistance to several antibiotics (multi drugs resistant) has caused serious problems for control of infections by this organism.

Usually most laboratories use conventional microbiological methods such as culture and biochemical procedures for identification of $P$. aeruginosa in clinical samples. On the other hand, conventional microbiological methods are time-consuming and take several days for identification and confirmatory testing, which is a prob- lem for controlling fatal infections (5). Also some P. aeruginosa strains are auxotrophs and their isolation results a false negative culture result which is fatal for patients susceptible to infection of this pathogen, such as patients with cystic fibrosis. Isolation of these strains needs selective and special culture media for growth and isolation, which are not routinely used in most laboratories (6). In some countries, serological methods are used to identify $P$. aeruginosa, however they are not reliable $(7,8)$. Recently the polymerase chain reaction (PCR) technique has been used as a molecular method to detect bacteria in clinical samples, yet this method needs to be improved, regarding sensitivity, specificity and expenses $(9,10)$.

\section{Objectives}

The aim of this study was to assess and compare the sensitivity and specificity of the conventional PCR technique

Copyright (C) 2014,Ahvaz Jundishapur University of Medical Sciences; Published by Kowsar. This is an open-access article distributed under the terms of the Creative Commons Attribution License, which permits unrestricted use, distribution, and reproduction in any medium, provided the original work is properly cited. 
by using two kinds of primers: specific primers published in previous articles (and designed highly specific precise primers for detecting the frequency of exoA (exotoxin A) found in $90 \%$ of $P$. aeruginosa strains (4), oprL (responsible for synthesis of a protein of the external membrane) and $\operatorname{alg} D$ gene (responsible for alginate synthesis) (11).

\section{Materials and Methods}

\subsection{Clinical Samples}

In this cross-sectional descriptive study, 150 clinical samples during a one-year period (February 2012 - February 2013) were collected from patients admitted in the ICU of Ashayer hospital (Khoramabad, Iran). The clinical samples consisted of: swabs from wounds 70 (46.6\%), sputa 20 (13.3\%), blood 5 (3.3\%), urine 5 (3.3\%), abscess 12 (8\%), Biopsy3 (2\%), cerebrospinal fluid 5(3.3\%), pulmonary secretion 27 (18\%) and synovial fluid 3 (2\%).

\subsection{Samples Preparation}

The samples were collected in two sterile microtubes for culture and PCR. For the PCR test $1000 \mu \mathrm{L}$ of PBS (phosphate buffer salts) was added in to the microtubes containing the patient's direct samples and the tubes were stored at $-70^{\circ} \mathrm{C}$. Microbiological culture of the samples was performed in the bacteriology lab using a suitable culture media such as MacConkey (Merck, Germany) agar and selective agar for isolation of organism and biochemical differential test reactions for identification of the isolates.

\subsection{Diagnosis of Pseudomonas aeruginosa Using Previously Published Primers}

Type of primers for amplification of the exoA and algD/oprL genes: two sets of primers were used for amplification of the exoA and algD/oprL genes, which had already been published in previous articles $(6,11,12)$, while newly designed primers based on the bioinformatics method were also examined. Characteristics of the previously published primers of the exoA, oprL and $\operatorname{alg} D$ genes such as size and nucleotides sequences, annealing temperature and available references are shown in Table 1.

To determine the sensitivity of the test, in addition to using the negative and positive controls, a couple of primers related to a conserved gene concerning the 16SrRNA, which are universally present in all strains, were used.

\subsection{Designing the Specific New Primers}

Three sets of $P$. aeruginosa specific primers were designed in this study. One set amplified a $125 \mathrm{bp}$ region of the exo $\mathrm{A}$ gene and the other two sets amplified a 105 and 126 bp region of the oprL and $\operatorname{algD}$ genes, respectively. The available sequences of these three genes were obtained from NCBI and multiple alignments were performed to find conserved sequences of each gene for primer design. Both multiple alignment and primer design steps were carried out by the AlleleID software, version 7.0 (Premier Biosoft International, Palo Alto, CA, USA). The primers were synthesized by TAG Copenhagen (Denmark). The sequence and position of each primer set is reported in Table 2.

\begin{tabular}{|c|c|c|c|c|}
\hline Target & PCR Program & Primer & Amplicon Size & Reference \\
\hline \multirow[t]{2}{*}{ rRNA S16 } & 40 cycles: $1 \min 94^{\circ} \mathrm{C}, 1 \min 55^{\circ} \mathrm{C}, 2 \min 72^{\circ} \mathrm{C}$ & F:5-GGGGGATCTTCGGAACCTCA-3 & 312 bp & $(6,11-14)$ \\
\hline & & R:5-TCCTTAGAGTGCCCAAACCCG-3 & & \\
\hline \multirow[t]{2}{*}{ exoA } & 40 cycles: $1 \min 96^{\circ} \mathrm{C}, 1 \min 55^{\circ} \mathrm{C}, 1 \min 72^{\circ} \mathrm{C}$ & F:5-GACAACGCCCTCAGCATCACCAGC-3 & 396 bp & $(6,11-14)$ \\
\hline & & R:5-CGCTGGCCCATTCGCTCCAGCGCT-3 & & \\
\hline \multirow[t]{2}{*}{ oprL } & 30 cycles: 40 s $94^{\circ} \mathrm{C}, 40$ s $57^{\circ} \mathrm{C}, 50$ s $72^{\circ} \mathrm{C}$ & F:5-ATGGAAATGCTGAAATTCGGC-3 & $504 \mathrm{bp}$ & $(6,11-14)$ \\
\hline & & R:3-CTTCTTCAGCTCGACGCGACG-3 & & \\
\hline \multirow[t]{2}{*}{ algD } & 30 cycles: $1 \min 94^{\circ} \mathrm{C}, 1 \min 60^{\circ} \mathrm{C}, 1 \min 72^{\circ} \mathrm{C}$ & F:5-TTCCCTCGCAGAGAAAACATC-3 & 520 bp & $(6,11-14)$ \\
\hline & & R:5-CCTGGTTGATCAGGTCGATCT-3 & & \\
\hline
\end{tabular}

\begin{tabular}{|c|c|c|c|}
\hline Bacterial Target & Sequence $5^{-}$to $3^{-}$ & ${\text {Primer Length }(b p)^{a}}^{a}$ & Amlicon Size (bp) \\
\hline exoA & & & 125 \\
\hline Sense Primer & ACATCAAGGTGTTCATCC & 18 & \\
\hline Anti-sense Primer & GACGAAGAAGGTGGCATC & 18 & \\
\hline oprL & & & 105 \\
\hline Sense Primer & TGCGATCACCACCTTCTACTTC & 22 & \\
\hline Anti-sense Primer & CGCTGACCGCTGCCTTTC & 18 & \\
\hline algD & & & 126 \\
\hline Sense Primer & ACGAAGTGGTGGCGAGTTC & 19 & \\
\hline Anti-sense Primer & TGGTGTGCGGCATGAAGC & 18 & \\
\hline
\end{tabular}




\subsection{Extraction and Purification of Bacterial DNA}

To prevent contamination of the samples with the preexisted DNA in the laboratory and to avoid creating false positive results, DNA extraction of samples, were performed under a biological, class II laminar flow cabinet. To extract bacterial DNA from the clinical samples, the DNA minikit (Invitec, Germany) was used according to manufacturer's instructions. Samples were directly enrolled in PCR or stored at $-80^{\circ} \mathrm{C}$ for future analysis. P. aeruginosa (ATCC 27853) was used as positive control in the PCR assay. DNA concentration and purity was determined by running the samples on $0.8 \%$ agarose gel based on the intensities of bands.

\subsection{PCR Reaction for Designed Primers}

\subsubsection{PCR Reaction for exoA Gene}

The reaction mixture of PCR was $25 \mu \mathrm{L}$ in a total volume containing $12.5 \mu \mathrm{L}$ of master mix (Cinaclone, Iran), $0.1 \mu \mathrm{L}$ of each primer, $2 \mu \mathrm{L}$ of genomic DNA, $0.5 \mu \mathrm{L}$ of $50 \mathrm{mM}$ $\mathrm{MgCl}_{2}$ and $9.8 \mu \mathrm{L}$ of distilled water $\left(\mathrm{dH}_{2} \mathrm{O}\right)$. PCR was carried out with an initial denaturation step of two minutes at $95^{\circ} \mathrm{C}$, followed by 35 cycles of denaturation ( 1 minutes at $95^{\circ} \mathrm{C}$ ), annealing (30 seconds at $56^{\circ} \mathrm{C}$ ) and extension $(1$ minutes at $\left.72^{\circ} \mathrm{C}\right)$; the reactions were finalized by an elongation step for five minutes at $72^{\circ} \mathrm{C}$.

\subsubsection{PCR Reaction for oprL Gene}

PCR was carried out in a total volume of $25 \mu \mathrm{l}$ with an initial denaturation step of two minutes at $95^{\circ} \mathrm{C}$, followed by 35 cycles of denaturation (two minutes at $95^{\circ} \mathrm{C}$ ), annealing ( 30 seconds at $56^{\circ} \mathrm{C}$ ), and extension ( 1 minute at $72^{\circ} \mathrm{C}$ ); the reactions were finalized by polymerization for five minutes at $72^{\circ} \mathrm{C}$.

\subsubsection{PCR Reaction for algD Gene}

PCR was carried out in a total volume of $25 \mu \mathrm{L}$ with an initial denaturation step of two minutes at $95^{\circ} \mathrm{C}$, followed by 35 cycles of denaturation (one minute at $95^{\circ} \mathrm{C}$ ), annealing ( 30 seconds at $55^{\circ} \mathrm{C}$ ) and extension (one minute at $72^{\circ} \mathrm{C}$ ); the reactions were finalized by polymerization for five minutes at $72^{\circ} \mathrm{C}$. Finally, the extracted DNA from Escherichia coli and standard strain of $P$. aeruginosa were used as negative and positive controls. In addition, a couple of specific primers for universal gene (16SrRNA) were used for all extracts to reconfirm the presence of $P$. aeruginosa.

\section{Results}

In the current study, of the 150 cultured clinical samples, 70 samples were positive for $P$. aeruginosa. Sensitivity and specificity of the results of the PCR method by using the designed primers and the published primers were compared with the results of the culture method as the gold standard. The positive results of the culture method and the positive and/or negative results of the PCR using designed and published primers are shown in Tables 1 and 2 .

All of the clinical isolates were diagnosed as negative through culture method were found to be negative using PCR with designed primers. However, PCR was able to detect 68 out of 70 samples were positive by culture method. The results of PCR for oprL gene were positive for all 70 culture positive samples. However, PCR results for $\operatorname{alg} D$ gene were positive for 69 out of 70 culture positive samples. By using the published primers for negative culture samples, the PCR results were also negative. PCR results for exoA gene were positive for 57 samples from 70 culture positive samples. PCR results of oprL gene were positive for 49 samples.

PCR results for $\operatorname{alg} D$ gene were only positive for 28 out of 70 culture positive samples. Sensitivity of the PCR by using the designed primers was calculated as $97.2 \%$ for $e x 0 A$ gene, $100 \%$ for oprL gene and $98.6 \%$ for $\operatorname{alg} D$ gene. Sensitivity of the PCR by using the published primers was $81.5 \%$, $70 \%$ and $40 \%$ for the exoA, oprL and $\operatorname{alg} D$ genes, respectively. The gel pictures of amplified genes are shown in Figure 1. According to the result of the negative and positive controls and by using the protected universal primers of rRNA, the specificity of the PCR tests for all cases was $100 \%$. From each PCR product of the designed primer, one sample was sequenced (Genfanavaran, Iran) to verify the amplified fragment. All of the obtained sequences were correctly verified.

Figure 1. Amplification of Targeted Genes for Diagnosis of Pseudomonas aeruginosa

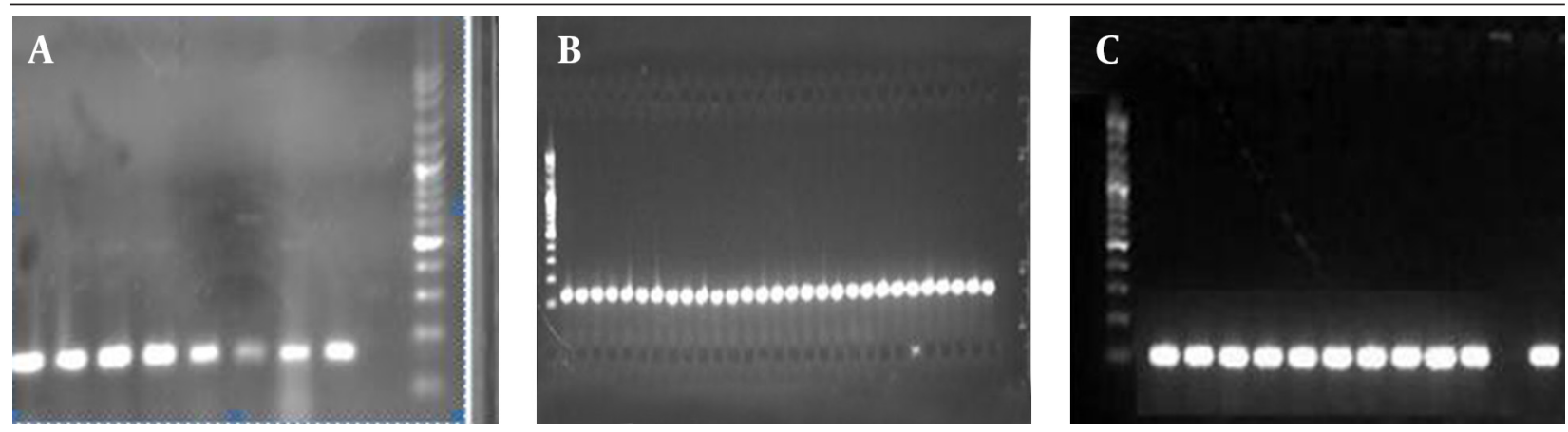

A) exoA gene (125 bp), B) algD gene (126 bp), C) OprL gene (105 bp). 100 bp ladder was used (Cinna clone, Iran). 
Rashno Taee S et al.

\begin{tabular}{|c|c|c|c|c|c|c|}
\hline Sample & 16SrRNA & algD & oprL & exoA & Culture & $\begin{array}{l}\text { No. of } \\
\text { Isolates }\end{array}$ \\
\hline Swab & + & + & + & + & + & 32 \\
\hline Sputum & + & - & + & - & + & 1 \\
\hline Sputum & + & + & + & + & + & 9 \\
\hline CSF & + & + & + & + & + & 3 \\
\hline Abscess & + & + & + & + & + & 10 \\
\hline Biopsy & + & + & + & + & + & 1 \\
\hline $\begin{array}{l}\text { Pulmonary } \\
\text { secretion }\end{array}$ & + & + & + & - & + & 1 \\
\hline Synovial & + & + & + & + & + & 1 \\
\hline $\begin{array}{l}\text { Exoda of } \\
\text { pulmonary }\end{array}$ & + & + & + & + & + & 12 \\
\hline
\end{tabular}

\begin{tabular}{|c|c|c|c|c|c|c|}
\hline Sample & 16SrRNA & $\operatorname{alg} D$ & oprL & exoA & Culture & $\begin{array}{l}\text { No. of } \\
\text { Isolates }\end{array}$ \\
\hline Wound swab & + & + & _- & + & + & 15 \\
\hline Wound swab & + & _- & + & + & + & 18 \\
\hline Sputum & + & _ & + & + & + & 5 \\
\hline Sputum & + & - & + & - & + & 3 \\
\hline CSF & + & + & + & + & + & 3 \\
\hline Biopsy & + & - & - & + & + & 1 \\
\hline $\begin{array}{l}\text { Pulmonary } \\
\text { secretion }\end{array}$ & + & - & - & + & + & 5 \\
\hline $\begin{array}{l}\text { Pulmonary } \\
\text { secretion }\end{array}$ & + & + & + & - & + & 10 \\
\hline Abscess & + & _ & + & + & + & 10 \\
\hline
\end{tabular}

\section{Discussion}

P. aeruginosa is an opportunist pathogen which during the recent decades, has been considered as a common agent of hospital acquired infections. The main reason for this condition is potential colonization factors like alginates and pilli and wide distribution of multi-drug resistance strains of this organism in hospital environments (4). P. aeruginosa is the most important cause of infection in patients with cystic fibrosis (CF). More than $80 \%$ of patients with CF are infected by this pathogen (15).

Identification of this bacterium in most laboratories is through conventional culture methods and isolation procedures, but culture from initial colonization in patients with cystic fibrosis is negative, however early detection of the organism in initial colonization is vital for these individuals (12). In addition, in patients admitted to the ICU and patients with level 3 burning, which have entered in the bacteremia phase, rapid identification of the bacteria via the conventional culture method and biochemical tests in a short time if not impossible, is very difficult (6). In addition, this bacterium is able to exist as auxotroph strains, which need special selective culture media for growth, and this makes its diagnostic more difficult. Therefore, false negative culture of patients sensitive to infection such as cystic fibrosis patients might be life threatening (13).

Another problem is that in most cases of burning patients there might be co-infection with other bacteria, thus repeated subcultures to isolate $P$. aeruginosa takes about 5-6 days. In this condition, only using a careful and rapid method can overcome the problems (6). In some European countries in order to identify these bacteria in patients with cystic fibrosis they use serological methods such as ELISA to detect antibodies (16), but the price of these methods depends on the kit and manufacturer and it sometimes could be more expensive. False positive results due to reactions with other bacteria including the Enterbacteriacae family are the other limitations of serological methods (17). Therefore, using the PCR method has priority to culture for detection of organisms at the beginning of the colonization especially in CF infections. Moreover PCR is more efficient than the culture method (18).

Various follow up studies during the recent years have shown that the PCR method has been able to detect bacteria at the beginning of colonization in CF patients, while the culture results are negative at the beginning of colonization in the above mentioned patients (14). In most of these follow ups, a positive culture is reported several weeks after organism colonization. Consequently, PCR is able to show the colonization of Pseudomonas, earlier than culture. It is obviously clear that having early information about colonization of the organism in high-risk patients is important for interventions by antibiotic therapy (14). Secondly, regarding patients with CF, throughout their life-time, they are often infected with a PA clone; surveying clone transfer among CF patients is impossible by the culture method $(19,20)$. In this study, DNA was extracted directly from clinical samples such as lung secretions, cystic fibrosis patients' sputum or swab from sever burning wounds, then by using two sets of specifically designed primers in this study and published in articles, the sensitivity and specificity of the PCR reaction was assessed.

Khan and Cerniglia used the PCR assay for identification of $P$. aeruginosa from clinical samples by designing specific primer for the exoA gene (21). Their results showed that this method has high specificity and is more suitable than biochemical methods. In 2000 Song et al, performed the same method using the exoA gene and confirmatory results were obtained (22). Another study was performed by Lanotte et al., in 2004 for detection P. aeruginosa using a couple of primers for oprL and exoA genes. The results illustrated that PCR with oprL gene produced higher sensitivity and specificity than the exoA gene; this is in accordance with our research (23). However the results of De Vos et al. research, which compared the oprL and oprI genes for detection of $P$. aeruginosa, demonstrated that 
the sensitivity of the PCR method using oprL gene is higher than oprI (24). Beside, Feizabadi et al. performed a real time PCR using the oprL gene. The sensitivity and specificity of this method was $100 \%$ and $98.85 \%$, respectively (4).

In addition Billard-Pomare et al. showed that qPCR of oprL gene has high specificity and it is more suitable than culture to show bacterial colonization (18). Moreover, Logan et al. compared PCR and conventional culture for colonization determination. They concluded that, compared to culture; PCR has higher sensitivity and specificity (14). In this study, several sputum samples were found positive through the PCR method while their cultures were negative. In most of our cases PCR samples become positive earlier once compared with culture investigations that their samples converted to positive during the time of hospitalization. This finding indicates that our method has sufficient sensitivity and specify to detect colonized patients (14). This could be considered as the advantage of this study.

In conclusion, the results of the present study showed that the PCR assay was able to detect $P$. aeruginosa infection in clinical samples earlier than conventional bacterial culture methods. It was also shown that by using newly designed primer sets for $\operatorname{alg} D$, oprL and exoA genes it is possible to detect infection more efficiently than previously published primer sets. This finding suggests that appropriately designed primers can increase both the sensitivity and specificity of a PCR assay. The results also emphasize that the PCR method has a great advantage over conventional culture in cases that timely treatment is important for patients' outcome.

\section{Acknowledgements}

This article is part of the work done by Sedighe Rashno Taee to fulfill the requirements for a Master of Science. The Authors acknowledge the Vice Chancellor for Research at Arak University of Medical Sciences for their financial support.

\section{Authors' Contributions}

Sedighe Rashno Taee: study design, sample collection, laboratory work and drafting of the manuscript. Behzad khansari Nezhad: study design, primer design and editing of the manuscript. Hamid Abtahi: study design, laboratory work and editing the manuscript. Mohammad Najafimosleh: study design. Ehsanollah Ghaznavi-Rad: study design, laboratory work and editing of the manuscript.

\section{Funding/ support}

This study was supported by the Vice Chancellor of research of Arak University of Medical Sciences (grant no: 720).

\section{References}

1. Macdonald D, Cuthbertson L, Doherty C, Campana S, Ravenni N,
Taccetti G, et al. Early Pseudomonas aeruginosa infection in individuals with cystic fibrosis: is susceptibility testing justified? $J$ Antimicrob Chemother. 2010;65(11):2373-5.

2. Estahbanati HK, Kashani PP, Ghanaatpisheh F. Frequency of Pseudomonas aeruginosa serotypes in burn wound infections and their resistance to antibiotics. Burns. 2002;28(4):340-8.

3. Ojielo CI, Cooke K, Mancuso P, Standiford TJ, Olkiewicz KM, Clouthier S, et al. Defective phagocytosis and clearance of Pseudomonas aeruginosa in the lung following bone marrow transplantation. J Immunol. 2003;171(8):4416-24.

4. Feizabadi MM, Majnooni A, Nomanpour B, Fatolahzadeh B, Raji N, Delfani S, et al. Direct detection of Pseudomonas aeruginosa from patients with healthcare associated pneumonia by real time PCR. Infect Genet Evol. 2010;10(8):1247-51.

5. Kidd TJ, Ramsay KA, Hu H, Bye PT, Elkins MR, Grimwood K, et al. Low rates of Pseudomonas aeruginosa misidentification in isolates from cystic fibrosis patients. J Clin Microbiol. 2009;47(5):1503-9.

6. Deschaght P, De Baere T, Van Simaey L, Van Daele S, De Baets F, De Vos D, et al. Comparison of the sensitivity of culture, PCR and quantitative real-time PCR for the detection of Pseudomonas aeruginosa in sputum of cystic fibrosis patients. BMC Microbiol. 2009;9:244.

7. Kappler M, Kraxner A, Reinhardt D, Ganster B, Griese M, Lang T. Diagnostic and prognostic value of serum antibodies against Pseudomonas aeruginosa in cystic fibrosis. Thorax. 2006;61(8):684-8.

8. da Silva Filho LV, Tateno AF, Martins KM, Azzuz Chernishev AC, Garcia Dde O, Haug M, et al. The combination of PCR and serology increases the diagnosis of Pseudomonas aeruginosa colonization/infection in cystic fibrosis. Pediatr Pulmonol. 2007;42(10):938-44.

9. McCulloch E, Lucas C, Ramage G, Williams C. Improved early diagnosis of Pseudomonas aeruginosa by real-time PCR to prevent chronic colonisation in a paediatric cystic fibrosis population. $J$ Cyst Fibros. 2011;10(1):21-4.

10. Williams HL, Turnbull L, Thomas SJ, Murphy A, Stinear T, Armstrong DS, et al. A diagnostic PCR assay for the detection of an Australian epidemic strain of Pseudomonas aeruginosa. Ann Clin Microbiol Antimicrob. 2010;9:18.

11. da Silva Filho LV, Levi JE, Oda Bento CN, da Silva Ramos SR, Rozov T. PCR identification of Pseudomonas aeruginosa and direct detection in clinical samples from cystic fibrosis patients. J Med Microbiol. 1999;48(4):357-61.

12. Xu J, Moore JE, Murphy PG, Millar BC, Elborn JS. Early detection of Pseudomonas aeruginosa--comparison of conventional versus molecular (PCR) detection directly from adult patients with cystic fibrosis (CF). Ann Clin Microbiol Antimicrob. 2004;3:21.

13. Deschaght P, Schelstraete P, Lopes dos Santos Santiago G, Van Simaey L, Haerynck F, Van Daele S, et al. Comparison of culture and qPCR for the detection of Pseudomonas aeruginosa in not chronically infected cystic fibrosis patients. BMC Microbiol. 2010;10:245.

14. Logan C, Habington A, Lennon G, Cronin F, O'Sullivan N. Evaluation of the efficacy of real-time polymerase chain reaction for the routine early detection of Pseudomonas aeruginosa in cystic fibrosis sputum and throat swab specimens. Diagn Microbiol Infect Dis. 2010;68(4):358-65.

15. Saiman L, Siegel J. Infection control in cystic fibrosis. Clin Microbiol Rev. 2004;17(1):57-71.

16. West SE, Zeng L, Lee BL, Kosorok MR, Laxova A, Rock MJ, et al. Respiratory infections with Pseudomonas aeruginosa in children with cystic fibrosis: early detection by serology and assessment of risk factors. JAMA. 2002;287(22):2958-67.

17. Hayes D, Jr, Farrell PM, Li Z, West SE. Pseudomonas aeruginosa serological analysis in young children with cystic fibrosis diagnosed through newborn screening. Pediatr Pulmonol. 2010;45(1):55-61.

18. Billard-Pomares T, Herwegh S, Wizla-Derambure N, Turck D, Courcol R, Husson MO. Application of quantitative PCR to the diagnosis and monitoring of Pseudomonas aeruginosa colonization in 5-18-year-old cystic fibrosis patients. J Med Microbiol. 2011;60(Pt 2):157-61.

19. Deschaght P, Van Daele S, De Baets F, Vaneechoutte M. PCR and the 


\section{Rashno Taee S et al.}

detection of Pseudomonas aeruginosa in respiratory samples of CF patients. A literature review. J Cyst Fibros. 2011;10(5):293-7.

20. Anuj SN, Whiley DM, Kidd TJ, Ramsay KA, Bell SC, Syrmis MW, et al. Rapid single-nucleotide polymorphism-based identification of clonal Pseudomonas aeruginosa isolates from patients with cystic fibrosis by the use of real-time PCR and high-resolution melting curve analysis. Clin Microbiol Infect. 2011;17(9):1403-8.

21. Khan AA, Cerniglia CE. Detection of Pseudomonas aeruginosa from clinical and environmental samples by amplification of the exotoxin A gene using PCR. Appl Environ Microbiol. 1994;60(10):3739-45.

22. Song KP, Chan TK, Ji ZL, Wong SW. Rapid identification of Pseu- domonas aeruginosa from ocular isolates by PCR using exotoxin A-specific primers. Mol Cell Probes. 2000;14(4):199-204.

23. Lanotte P, Watt S, Mereghetti L, Dartiguelongue N, Rastegar-Lari A, Goudeau A, et al. Genetic features of Pseudomonas aeruginosa isolates from cystic fibrosis patients compared with those of isolates from other origins. J Med Microbiol. 2004;53(Pt1):73-81.

24. De Vos D, Lim AJ, Pirnay A, Jr, Struelens M, Vandenvelde C, Duinslaeger L, et al. Direct detection and identification of Pseudomonas aeruginosa in clinical samples such as skin biopsy specimens and expectorations by multiplex PCR based on two outer membrane lipoprotein genes, oprI and oprL. J Clin Microbiol.1997;35(6):1295-9. 